\title{
TEKNIK CASTING PADA PERHIASAN GUNA MENUNJANG DAYA BELI
}

\section{Pandansari Kusumo}

Program Studi Desain Produk ISI Yogyakarta Email: pandansarikusumo@gmail.com

\section{ABSTRACT}

Along with the development of jewelry in Indonesia, several techniques of making are used. In the design of industrial products, jewelry by casting technique is one of the techniques of making jewelry in bulk; using several models of jewelry will obtain many products of casting at the same time. This casting techniue is very supportive in the process of production, working efficiently and also cost efficient. But when the jewelry products are made manually, it will not achieve high productivity results as expected.

Keywords: casting technique, efficiency, high productivity

\begin{abstract}
ABSTRAK
Dengan berkembangya perhiasan di Indonesia, berbagai teknik pembuatan perhiasan digunakan, Dalam desain produk industri, perhiasan dengan teknik tuang atau casting adalah merupakan salah satu teknik pembuatan perhiasan secara massal, yaitu dengan menggunakan beberapa model perhiasan akan memperoleh hasil cetak secara banyak dalam waktu yang bersamaan, hal ini sangat mendukung dalam proses produksi, efisiensi kerja dan efisiensi biaya. Akan tetapi apabila produk perhiasan dibuat secara manual, maka tidak akan tercapai produktivitas tinggi sesuai yang diharapkan.
\end{abstract}

Kata kunci: teknik tuang, efisiensi, produktivitas tinggi

\section{Pendahuluan}

Dunia fashion tidak pernah lepas dari dunia perhiasan, karena perhiasan adalah salah satu hal yang penting dalam menunjang penampilan seseorang. Banyak orang tampil dengan mengenakan perhiasan agar dapat menambah keindahan dalam penampilannya dan percaya diri. Dalam berbagai acara, seseorang akan tampil lebih cantik dan elegant dengan menggunakan perhiasan, tetapi dalam memakai perhiasan tidak perlu berlebihan. Pada umumnya manusia menggunakan perhiasan karena ingin terlihat menarik dan cantik, bahkan saat ini para pria pun senang mengenakan perhiasan. Perhiasan ini ada bermacam-macam kriterianya, yaitu perhiasan pesta dan perhiasan yang dipakai untuk sehari-hari. Perbedaannya adalah kalau perhiasan pesta itu biasanya terlihat lebih mewah, meskipun tidak menggunakan bahan baku emas, tapi penampilan dari perhiasan tersebut terlihat lebih glamour. Sedangkan perhiasan yang digunakan sehari-hari itu, terlihat lebih sederhana.

Di era globalisasi ini semua berkembang serba cepat, demikian juga perkembangan perhiasan; perhiasan juga akan selalu berkembang mengikuti jaman. Mulai dari mode/model, bahan baku, teknik pembuatan maupun cara memasarkannya. Dalam desain produk industri, perhiasan dengan teknik casting adalah merupakan salah satu teknik pembuatan perhiasan secara massal, yaitu dengan menggunakan beberapa model perhiasan akan memperoleh hasil cetak secara banyak dalam waktu yang bersamaan, hal ini 
sangat mendukung dalam proses produksi, efisiensi kerja dan efisiensi biaya. Akan tetapi apabila produk perhiasan dibuat secara manual, maka tidak akan tercapai hasil produktifitas yang tinggi sesuai yang diharapkan.

Perkembangan desain selalu mengikuti perkembangan jaman, sehingga pasti akan muncul trend - trend yang baru. Trend tersebut biasanya akan mampu menguasai pasar, meskipun ada banyak sekali jenis perhiasan dipasaran. Bentuk atau desain yang berkualitas, harga yang terjangkau akan menarik pembeli dan pasti akan dapat menguasai pasar, karena pelaku pasar adalah salah satu kunci sukses atau tidaknya suatu produk di pasaran.

Adapun jenis perhiasan ini dapat digolongkan, mulai dari bentuk, teknik hingga bahan bakunya sangat beragam. Dari bentuknya berupa cincin, kalung, antinganting, giwang, gelang, dsb. Dilihat dari tekniknya, yaitu: teknik manual dan industri/mesin. Dilihat dari bahan bakunya, yaitu: terbuat dari emas, perak, gelas/kaca, benang,plastik, keramik, batu, dan lain sebagainya.Akhir-akhir ini dunia perhiasan sangat marak dengan adanya "bom" batu permata, dengan mudah kita bisa menemui pedagang perhiasan tersebut, hampir disetiap sudut, disetiap jalan dapat kita temui. Ratarata pedagang tersebut menjual produk cincin dan kalung dengan bahan baku logam. Beberapa jenis logam yang diguankan antara lain, yaitu logam alpaka, logam titanium, logam kuningan, dan perak. Bahan-bahan ini biasa digunakan untuk membuat perhiasan dengan teknik casting.

Ada beberapa pendapat mengenai perhiasan ini, seperti yang dituliskan dalam beberapa buku antara lain sebagai berikut. Wanita dan perhiasan seolah tak dapat dipisahkan. Hal itu bisa dilihat dari sejarah, karena sejak jaman prasejarah, manusia sudah mengenal pemakaian perhiasan. Peninggalanpeninggalan pada jaman ini menunjukkan, bahwa naluri menghias diri pada manusia sudah tumbuh dan berkembang bersamaan dengan perkembangan peradaban manusia itu sendiri. Dan ternyata banyak bukti-bukti yang menunjukkan bahwa, semakin tinggi peradaban manusia, akan semakin tinggi pula mutu perhiasan yang dihasilkan. (Sumartono (Penterj.), 1995/1996:1)

Perhiasan juga dapat menjadi ciri status bagi pemakainya, seperti yang dituliskan dalam buku The Art Of Making Jewelry dituliskan, bahwa perhiasan adalah bagaikan icing/hiasan di atas cake atau pita yang menghiasi sebuah kado. Perhiasan bisa digunakan sebagai ciri khas atau identitas seseorang. Memberikan keindahan dan kesempurnaan bagi penampilan seseorang. Dalam setiap satu jenis perhiasan terkandung didalamnya yaitu satu keindahan, sebuah hadiah dan pelengkap. (Krupenia, Powley \& J Wrobel; 2005)Perhiasan adalah hasil kerajinan logam yang mempunyai fungsi sebagaipelengkap dalam tata busana. Jenis-jenisnya meliputi tusuk konde, bros, kalung, ikat pinggang. Gelang, anting, cincin, subang, peniti, jepit dasi, kancing baju, dan lain sebagainya. (Sunaryo \& Sri B, 1979:19).

\section{Bahan Baku Perhiasan}

Ada banyak bahan baku yang dapat digunakan untuk perhiasan, diantaranya logam, plastik, kayu, gelas/kaca, keramik, batu, dan lain sebagainya. Semua bahan baku tersebut mudah diperoleh dipasaran. Bahan baku ini sangat berperan dalam proses pembuatan perhiasannya, karena masingmasing bahan memiliki kekhasan. Demikian juga halnya dengan bahan baku dari logam, jenis satu logam dengan jenis logam yang 
lainnya sudah dapat dipastikan memiliki keistimewaan sendiri-sendiri. Hal ini diakibatkan karena jenis, sifat, kekerasan, titik didih logam yang berlainan, sehingga tidak semua jenis logam dapat digunakan untuk perhiasan.

Produk perhiasan logam yang beredar dipasaran pada umumnya adalah produk perhiasan berupa cincin dan kalung. Bahan yang banyak digunakan antara lain, yaitu: logam titanium, rodium, perak, kuningan, germanium dan alpaka. Logam-logam tersebut adalah merupakan jenis logam yang ada di dunia dan merupakan jenis logam yang dapat diproduksi dengan menggunakan teknik casting atau lost wax.Beberapa jenis logam yang dapat digunakan untuk membuat perhiasan dengan teknik casting/ lost wax antara lain, yaitu:

1. Logam Rodium: Rodium memiliki warna putih keperakan dan apabila dipijarkan perlahan-lahan di udara, a kan berubah menjadi resquioksida.Logam ini memiliki titik cair yang tinggi, yaitu $19850^{\circ} \mathrm{C}$ dan bobot jenis yang lebih rendah dari platina. Pada suhu yang lebih tinggi, resquioksida akan kembali menjadi unsur rodium. Sifat lain dari rodium adalah reflektif, keras dan tahan lama serta sangat tahan terhadap berbagai bentuk pengaruh asam.

2. Logam Ge (Germanium), ciricirinya: 1. Padat, abu-abu mengkilap. 2. Dalam bentuknya yang murni, germanium berbentuk kristal dan rapuh. 3. Unsur ini memiliki sifat kimia dan fisika mirip silikon. Germanium stabil di udara dan air, serta tidak terpengaruh oleh asam dan basa, kecuali asam nitrat. Logam ini ditemukan oleh Clemens Winkler pada tahun 1886.

3. Logam titanium, adalah sebuah unsur kimia yang memiliki simbol Ti. Unsur ini merupakan jenis logam transisi yang ringan, kuat, berkilau, tahan korosi (termasuk tahan terhadap air laut, aqua regia, dan klorin) dengan warna putih metalik, keperakan. Logam ini ditemukan oleh William Gregor di daerah Cornwall, kerajaan Britania Raya pada tahun 1791.

4. Logam monel adalah logam nirkarat (tahan karat), yang terdiri dari 67\%nikel dan 30\% tembaga $(\mathrm{Cu})$, serta sedikit unsur-unsur besi, sulfur atau yang lain. Monel tahan pada korosi, berwarna putih keperak-perakan. Logam monel biasanya digunakan untuk membuat alat-alat dapur, alat-alat rumah sakit, alat-alat setrika dan juga produk perhiasan. (https://ms.wikipedia.org/wiki/Mo nel)

Nuvola kdict glass.png Etimologi

5. Logam Perak memiliki nama unsur kimia (Ag), lambangnya berasal dari bahasa Latin. Perak merupakan logam transisi lunak, warna putih, mengkilapdan memiliki konduktivitas listrik dan panas tertinggi di seluruh logam dan terdapat di mineral dalam bentuk bebas. Perak merupakan logam mulia karena tidak mengalami proses korosi, namun perak mengalami proses oksidasi. Proses oksidasi ini mengakibatkan munculnya lapisan kehitaman pada permukaan perak yang disebut 
"tarnish". Akan tetapi oksidasi ini tidak mengakibatkan kerusakan pad aunsur tersebut.

6. Logam emas adalah logam mulia dan komoditas yang sangat berharga dalam sepanjang sejarah. Emas memiliki nama kimia $\mathrm{Au}$ atau aurum, termasuk golongan native element, dengan sedikit kandungan perak, tembaga, atau besi. Warnanya kuning keemasan dengan kekerasan 2,5-skala Mohs. Spesifik gravity 15, 5-19, 3 pada emas murni.

Pada masa sekarang masyarakat sedang menggemari perhiasan cincin dan kalung dengan bahan logam, seiring dengan adanya bom "batu permata" di pasaran.

\section{Teknik Pengerjaan}

Teknik pengerjaan perhiasan juga dapat dilakukan dengan cara bermacam-macam, antara lain teknik pahat manual, teknik dreg dan teknik casting (lost wax). Pertama pengerjaan dengan teknik pahat manual biasanya digunakan untuk pembuatan produk dengan alat pahat, yang dikerjakan secara perlahan-lahan dan craftmanship yang tinggi. Hasilnya dapat perfect, tapi memerlukan biaya yang cukup tinggi karena memerlukan waktu yang lama, sehingga kurang cocok jika teknik ini digunakan dalam produksi. Kedua teknik dreg, teknik ini sebenarnya juga dapat digunakan untuk memproduksi beberapa barang, hanya saja teknik ini biasanya dikerjakan satu persatu dengan menggunakan cetakan yang dibuat terlebih dulu, cetakan dreg ini biasanya terbuat dari logam keras yang biasa digunakan untuk rel Kereta Api yaitu logam baja. Teknik ini biasanya hanya dapat menggunakan logam dengan ketebalan tertentu, karena jika menggunakan logam yang tebal, maka hasilnya hiasannya tidak akan terlihat jelas. Ketiga Teknik casting/lost wax, teknik ini biasanya digunakan dalam memproduksi suatu barang yang sifatnya massal, karena teknik ini sangat efisien dalam pengerjaan dan biaya produknya juga lebih murah. Teknik casting ini juga banyak digunakan untuk membuat produk perhiasan, dengan tujuan untuk mendapatkan hasil yang lebih banyak dengan biaya yang miring. Teknik ini menggunakan cetakan yang dapat digunakan selama berkali-kali. Jenis perhiasan disini dirancang sedemikian rupa, sehingga tercipta bentuk-bentuk yang indah. Beberapa daerah atau negara penghasil perhiasan dengan teknik casting, antara lain, yaitu China, Korea, Indonesia (Surabaya, Bali).

Saat ini desain dan pembuatan perhiasan tidak lagi menjadi tugas yang sulit, karena dengan menggunakan software $3 \mathrm{D}$ dan rapid prototyping (RP) desain perhiasan terus tumbuh di seluruh industri, oleh karena itu hal ini sangat memberikan kebebasan bagi desainer-desainer kreatif dalam mewujudkan hasil karyanya. 
Bagan Proses Pembuatan Perhiasan dengan Teknik Casting
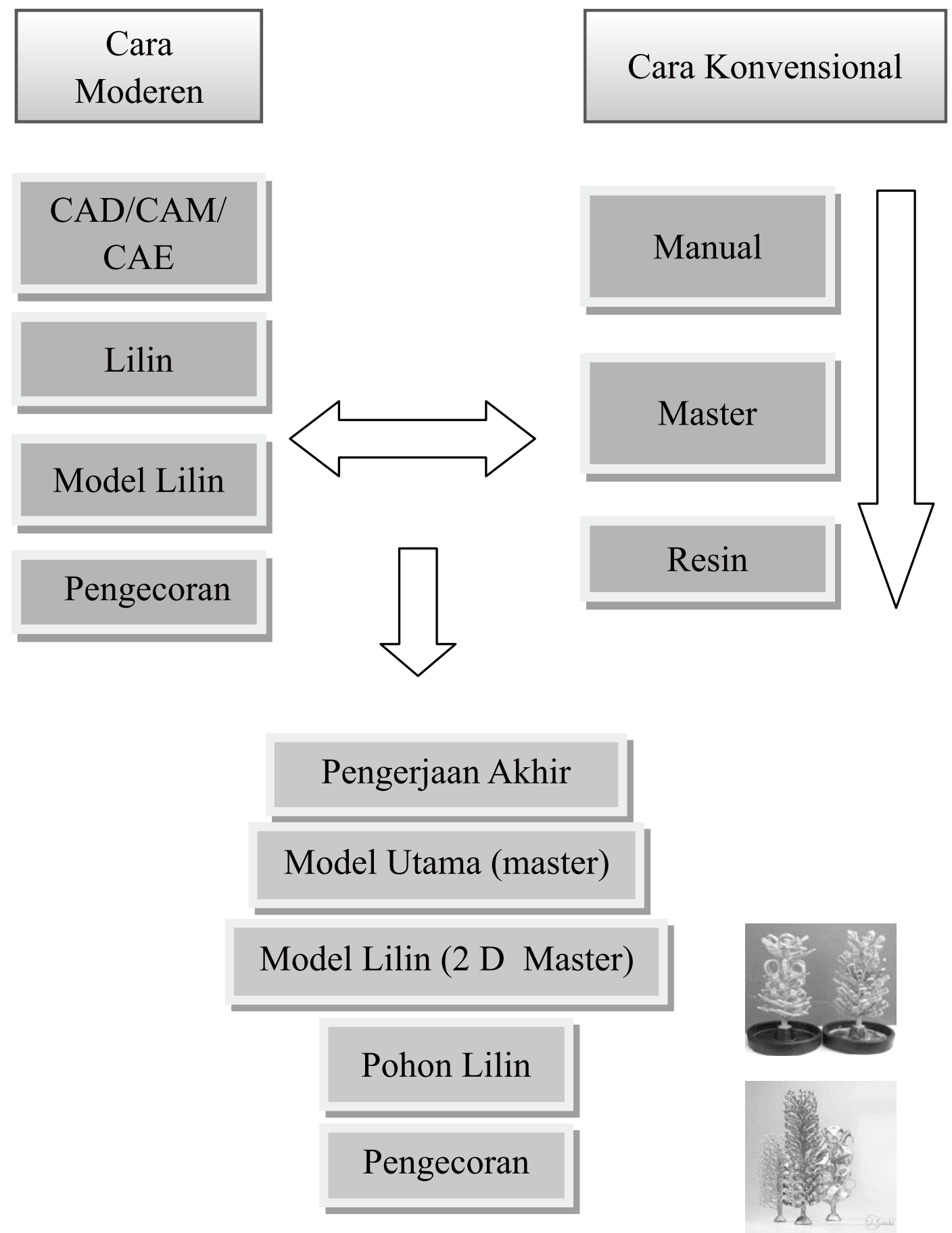


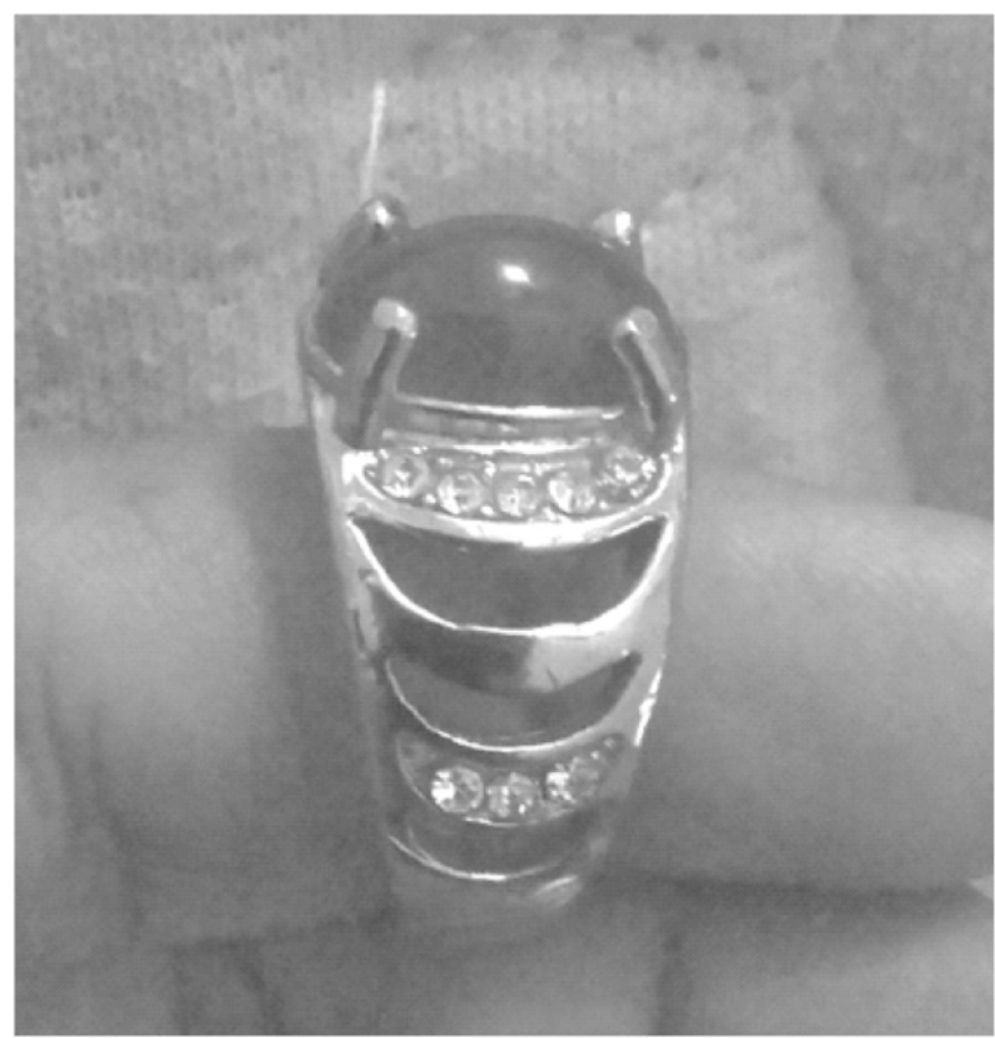

Contoh 1. perhiasan yang dibuat dengan teknik casting: (Sumber: Koleksi Pandansari Kusumo)

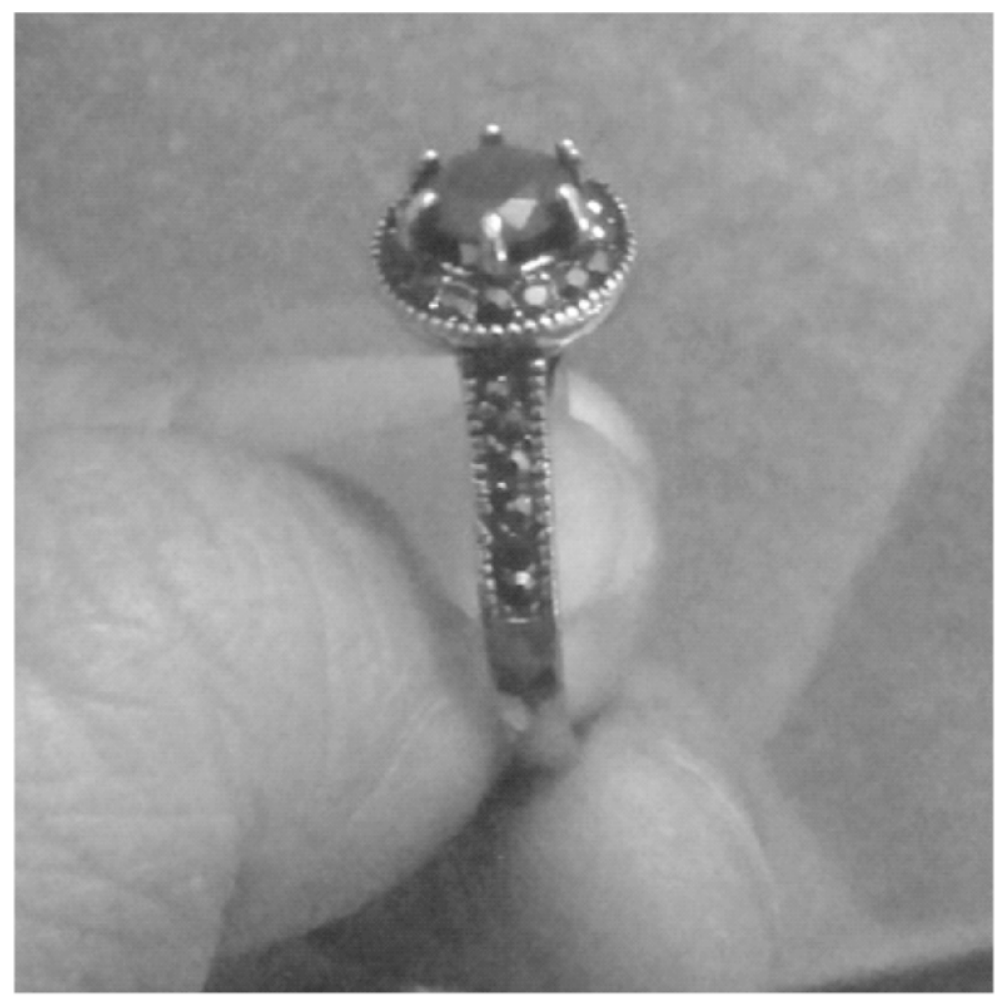

Contoh 2. perhiasan yang dibuat dengan teknik casting: (Sumber: Koleksi Pandansari Kusumo) 


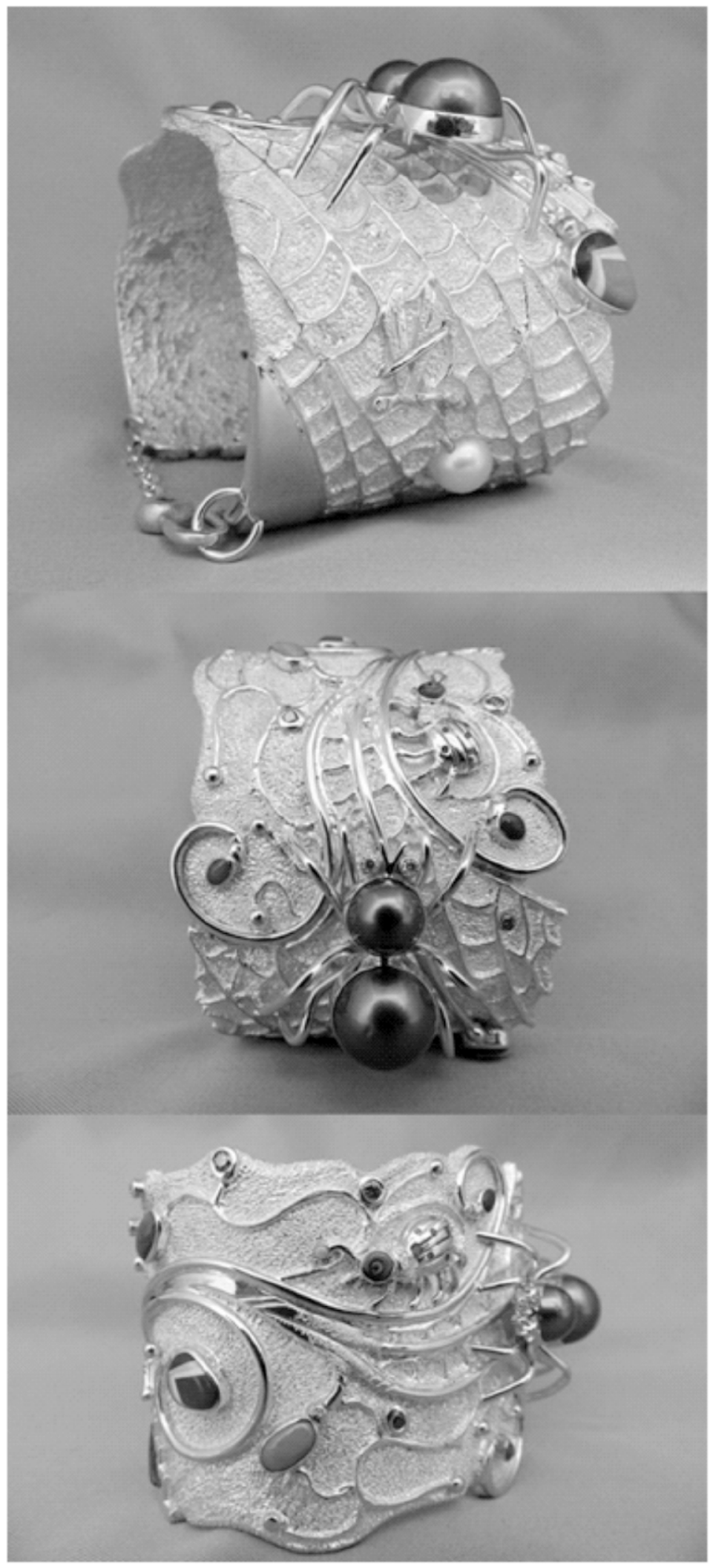

Contoh 3. perhiasan yang dibuat dengan teknik casting: (Sumber: httpsid.pinterest.compin441493569695733418 22/02/2016, jam 12.05) 


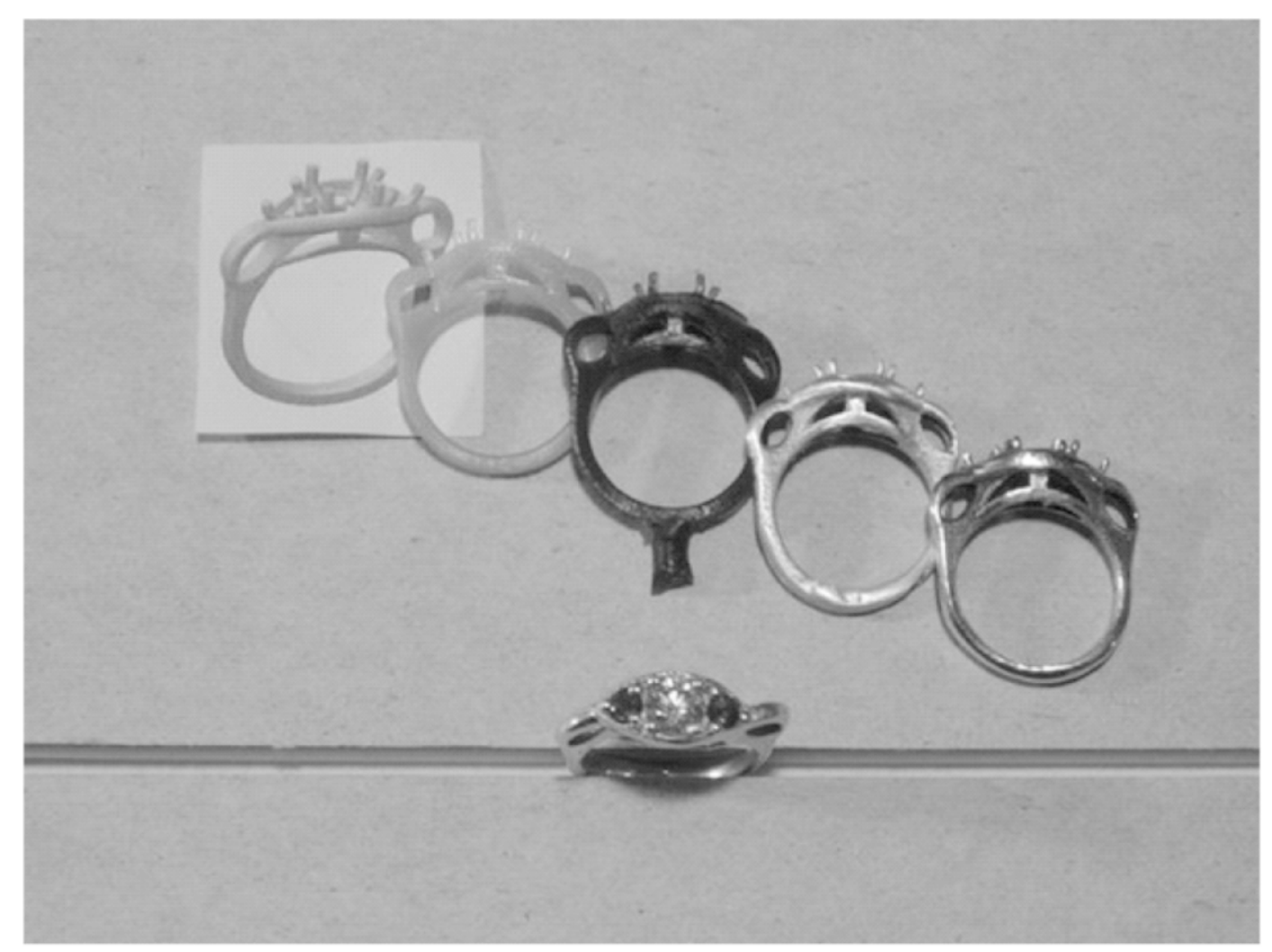

Contoh 4. perhiasan yang dibuat dengan teknik casting: (Sumber: https://id.pinterest.com/pin/334462709803691856/ 22/02/2016, jam 11:55)

\section{DAFTAR PUSTAKA}

Sumartono (Penterj.), (1995/1996),

"Album Perhiasan Tradisional",

Depdikbud, Jakarta.

Sunaryo, S. Hudi dan A. Sri Bandono, (1979), "Pengetahuan Teknik Logam I", Direktorat Pendidikan Menengah Kejuruan, Jakarta.

Krupenia, Deborah, Tammy Powley, Jessica Wrobel, (2005), The Art Making Jewelry, Thunder Bay Press, San Diego, California. 